\title{
Study of in vitro activity on glucose uptake of 3T3L1 cells, RIN5f cells, and glycemic index stimulation inhibitory effect of Abutilon indicum (L.) extract
}

\author{
L. Lavanya ${ }^{1}$, V. Veeraraghavan ${ }^{1 *}$, Renuka Srihari $^{2}$, C. N. Prashantha ${ }^{3}$ \\ ${ }^{1}$ Department of Biochemistry, School of Applied Sciences, REVA University, Bengaluru, India. \\ ${ }^{2}$ Department of Biochemistry, Maharani Lakshmi Ammani College for Women, Bengaluru, India. \\ ${ }^{3}$ Department of Biotechnology, School of Applied Sciences, REVA University, Bengaluru, India.
}

\begin{tabular}{l}
\hline ARTICLE INFO \\
\hline Article history: \\
Received on: May 17, 2021 \\
Accepted on: August 03, 2021 \\
Available online: January 07, 2022 \\
\hline
\end{tabular}

Key words:

A. indicum (L.), diabetes mellitus, glucose uptake of 3T3L1 cell, glycemic index, RIN5f cells

\begin{abstract}
Abutilon indicum (L.) is one of the traditional medicinal plants and its extract has been utilized for antidiabetic activity. Diabetes mellitus is a metabolic disorder characterized by hyperglycemia and its occurrence is increasing fast in most countries. Peroxisome proliferator-activated receptor gamma (PPAR $\gamma$ ) plays an important role in adipogenesis. The present study determines the effect of $A$. indicum methanolic leaf extract as potential antidiabetic inhibitors. The in vitro analysis was carried out by using 3T3L1 for glucose uptake assay, RIN5F cell lines for insulin secretion, hydrolysis assay to predict glycemic index, 1,1-diphenyl-2-picryl hydrazyl (DPPH) radical scavenging assay, and molecular interaction of the known bioactive compounds with PPAR $\gamma$. The experimental results showed $100 \mathrm{nM}$ insulin and $50 \mathrm{mM} \mathrm{LiCl}$ glucose uptake with 3.37 and 3.86 fold stimulation, respectively, when compared to the control, whereas the given samples of 200, 400, and 800 $\mu \mathrm{g} / \mathrm{ml}$ showed $1.37,1.62$, and $1.85 \mu \mathrm{g} / \mathrm{ml}$ fold stimulation, respectively, when compared to the control. The insulin release in RIN-5f cells was observed with a positive control and crude extract and the results showed 4.67 and $2.67 \mu \mathrm{g} / \mathrm{ml}$, respectively. The hydrolysis index value was found to be 53.30 and the glycemic load was $17.48 \mu \mathrm{g} / \mathrm{ml}$. In the DPPH assay, the sample showed dose-dependent DPPH radical scavenging activity with an $\mathrm{IC}_{50}$ value of $99.12 \mu \mathrm{g} / \mathrm{ml}$ when compared to standard quercetin with an $\mathrm{IC}_{50}$ value of $1.7 \mu \mathrm{g} / \mathrm{ml}$. The molecular interaction of PPAR $\gamma$ and active methyl trans-p-coumarate $(-5.44)>$ methyl caffeate $(-4.49)>$ syringic acid $(-3.9)>$ pinellic acid $(-2.62)$ compared with thiazolidinediones $(-7.62)$ formed a novel type of oral antidiabetic medication that improved metabolic management in type 2 diabetic patients by increasing insulin sensitivity. The overall result shows that A. indicum (L.) is a potential indicator for sensitizing insulin secretion and strongly inhibits the release of glucagon which can be used as a therapeutic agent for treating and managing diabetes.
\end{abstract}

\section{INTRODUCTION}

Diabetes mellitus (DM) is a non-communicable and endocrinebased disorder with vascular complications characterized by atherosclerosis, nephropathy, neuropathy, retinopathy, and other cardiovascular disorders resulting in organ and tissue damage, contributing to the global healthcare burden [1-3]. Worldwide,

\footnotetext{
*Corresponding Author

V. Veeraraghavan, Department of Biochemistry, School of Applied Sciences, REVA University, Bengaluru, India.

E-mail:Veera.raghavan449@gmail.com
}

347 million people suffer from DM. It will rank seventh among all the causes of death by 2030 [4], and it is projected that the global incidence of diabetes in 2019 which was 9.3\% (463 million) will rise to $10.2 \%$ (578 million) by 2030 and $10.9 \%$ (700 million) by 2045. The frequency ought to be greater in urban areas $(10.8 \%)$ than in rural areas $(7.2 \%)$ and in high-income areas $(10.4 \%)$ than in low-income countries $(4.0 \%)$. The current lifestyle has posed a substantial detrimental influence on the sedentary population with increased weight $[5,6]$. About $90 \%$ of all cases of diabetes in various countries are noninsulin-dependent DM [7]. Type $2 \mathrm{DM}$ is the insulin resistance-related metabolic dysfunction and persistent hyperglycemia has catastrophic consequences 
and is one of the world's most serious public health issues [8]. Despite the availability of several traditional medicines, such as thiazolidinediones (TZDs), metformin, sulfonylureas, dipeptidyl peptidase 4 inhibitors, glucagon-like peptide 1 , and sodiumglucose cotransporter-2 inhibitors, side effects still persist [9].

The present epidemiological status of diabetes has covered the researchers for their new novel studies targeting the eradication of this incurable disease. Characterization of several complications in DM is basically altered due to metabolisms of protein, carbohydrate, and fats resulting in the lack of insulin secretion [10]. As for now, the diabetic treatment is reported to cause a lot of side effects, but herbal floras can be utilized because of their minimal side effects, efficacy, relatively low costs, and ease of access. A large number of herbal plants have been exploited vastly for medication since ancient times for the treatment of many diseases. Several populations are dependent on these conventional methods, such as Siddha, Ayurveda, Unani, and herbal medicines, and their extracts are widely prescribed, even when their biologically active compounds are unknown [11]. Even the World Health Organization (WHO) has approved employing some plants as medication for different disorders including DM [12].

Ethnomedicinal plants are precious products from nature to mankind, and they are excellent sources of many phytochemicals utilized in human and animal health diets [13]. According to the WHO [14], over $80 \%$ of the population in poor nations rely on traditional, plant-based medicines for their healthcare needs. Phytochemicals are secondary metabolites secreted by plants for defense purposes, and research demonstrates that these phytochemicals may be utilized to successfully and safely cure a variety of illnesses [15]. Phytoconstituents come in a variety of forms, each with its own set of pharmacological and therapeutic characteristics. In vitro assays can be employed as early screening methods for evaluating the antidiabetic efficacy of medicines, allowing for the screening of a large number of prospective treatment candidates. They might give helpful information on medicinal drugs' mechanisms of action [16].

It has been estimated that more than a thousand plant species are being used as folk medicine for curing diabetes. Herbal products or plant products are rich in flavonoids, phenolic compounds, terpenoids, and other constituents which help to reduce blood glucose levels [17,18]. Abutilon indicum, an erect, branched shrub of $0.5-1 \mathrm{~m}$ height, with the Thai names Krob-Fun-Si, Fun-Si, or Ma-Kong-Khaao, is the native Southeast Asian plant. It is a small shrub belonging to the Malvaceae family, native to tropical and subtropical regions and sometimes ornamentally cultivated in Karnataka and Tamil Nadu. This plant has a long tradition of being used medicinally as an antidiabetic treatment and is found to include alkaloids, flavonoids, tannins, saponins, and glycosides through phytochemical screening [19]. It has revealed the presence of a diversity of secondary metabolites which are responsible for its biological activities such as antipyretic, antiviral, antimalarial, anti-venom, antibacterial, cytotoxic, anti-hyperglycemic, antiurolithiatic, anti-hyperlipidemic, gastroprotective, antidiarrheal, wound healing, antihypertensive, antioxidant, immunostimulant, diuretic, antifungal, analgesic, anti-inflammatory, aphrodisiac, anthelmintic, and hepatoprotective [20].
Abdul et al. [22] explained the cytotoxicity of crude methanolic leaf extract of $A$. indicum. In brine shrimp lethality bioassay, $\mathrm{LC}_{50}$ obtained from the best-fit line slope were $0.419,3.01,5.62,1.51$, and $11.20 \mu \mathrm{g} / \mathrm{ml}$ [21]. 3T3L1 cells represent a good model for the uptake of glucose because they have been vastly used to elucidate the mechanism in the uptake of glucose in muscle cells and also have intact insulin signaling pathways and express insulin-sensitive glucose transporter type 4 (GLUT 4) transporters [23-25]. Cells that have an elevated glucose level, which are measured by beta cells in the pancreas, release insulin into the bloodstream. The mechanism of movement of insulin through the blood precisely binds to the receptors found in the cell membrane, including brain cells, liver, muscle cells, adipose, etc. Due to elevated blood glucose levels, the opening of gated ion channels, such as voltage-dependent $\mathrm{Ca}+$ channels and $\mathrm{Ca}+$ channel concentration, is increased by insulin released by ATP-mediated cell depolarization [26]. For several experiments on cell functions, the RIN5 $\mathrm{f}$ cell lines help to promote, including insulin gene expression, metabolism, glucose transfer, and release of insulin. RIN5F cells are primarily susceptible to the release of insulin triggered by glyceraldehyde but not responsive to glucose. Therefore, at some levels of glucose concentration, the use of glucose exceeds a high intensity and is hyperbolic in nature [27].

As the current lifestyle of the people is changing day by day, proper monitoring of the diet and its assessment is a must to control the blood glucose level. The glycemic index (GI) is an evaluation of the increase in blood glucose levels from the intake of different food materials. The main principle behind GI is the recommendation of foods to consume in order to regulate the GI for people suffering from or on the brink of developing DM. A comparison of the meal tested and the isoglucosidic check meal after intake shall be used to determine GI for any food content. Monosaccharide glucose induces a broad glycemic reaction and often serves as the benchmark food. Initially, people with diabetes, due to their poor GI, used to use fructose as an alternative sweetener. Minimal amounts of fructose have been shown to enhance glucose metabolism by causing glucokinase. As a consequence, glycogen production increases and hepatic cell performance decreases. Fructose, however, has been a primary issue over the past decade with respect to its role in the epidemics of obesity, diabetes, and cardio metabolic complications. Ecologically generated findings have linked increasing fructose intake to increased obesity $[28,29]$.

The use of bioactive phytochemicals for treating obesity has gained increasing recognition in new pharmacological agents in recent years [30]. In the current research work, we studied in vitro and in silico molecular docking interactions with models designed to activate particular antidiabetic targets to examine the antidiabetic efficacy and mechanism of action. In addition, we imply determining the GI of $A$. indicum leaves in vitro using 3T3L-1 cells, insulin release in RIN5f cells, and glucose absorption in 3T3L-1 cells.

\section{MATERIALS AND METHODS}

\subsection{Cell Lines, Media, Assay Kits, and Reagents}

3T3L-1 cells were procured from American Type Culture Collection (ATCC) [CL-173]; $\alpha$-minimum essential medium and insulin from Sigma; fetal bovine serum (FBS) and antimycotic from Invitrogen; 
Dulbecco's modified eagle medium (DMEM) from Gibco; bovine serum albumin, dexamethasone, isobutylmethylxanthine (IBMX), insulin, $\mathrm{LiCl}$ and 2-deoxy[14C]glucose from GE-Amersham. 0.1 $\mathrm{M} \mathrm{KH} \mathrm{PO}_{4}$ buffer solution ( $\mathrm{pH}$ 6.9) and $\mathrm{H}_{3} \mathrm{PO}_{4}$ were from Pure Chemicals Co.; trypsin was from Sigma-Aldrich; rat insulin ELISA kit was from Kinesis DX, California (Cat. No. K110708); and the dialysis bags were from Surni Labs.

\subsection{Plant Material}

The plant sample $A$. indicum (L.) was collected from "Krishnendra botanical plant nursery" Lalbagh, Bengaluru. Taxonomy identification accession number is UASB-4604 from the Botanical Garden University of Agriculture Sciences, GKVK, Bengaluru.

\subsection{Preparation of Plant Extract}

Fresh green leaves of $A$. indicum (L.) were collected and washed thoroughly under running tap water, followed by distilled water, to remove the dirt. The leaves made into a powder by grinding after shade drying. Powdered leaf samples were then sieved, weighed, and stored in an airtight container for experimental use. The powder $(5 \mathrm{~g})$ was measured and mixed with $95 \%$ methanol $(50 \mathrm{ml})$ in the dark at $28^{\circ} \mathrm{C}$ for 24 hours and shaken $(150 \mathrm{rpm})$. In order to obtain the extract, the mixture was filtered through a muslin cloth and a Whatman (No. 1) filter paper. The filtrate leaf extract was evaporated in a rotary evaporator at $50 \mathrm{~mm}$ high pressure at $50^{\circ} \mathrm{C}$. As evaporated leaf extracts are viscous and thick, they are stored in air-tight bottles and frozen at $20^{\circ} \mathrm{C}$ until analyzed.

\subsection{Procedures and Protocol for Glucose Uptake Assay}

\subsubsection{Glucose uptake assay}

GSK-3 inactivation promotes glucose absorption in 3T3L-1 differentiated cells (adipocytes), which may be detected using 2-deoxy-[14C]glucose and quantified using a scintillation counter.

2.4.1.1. Differentiation of 3T3L-1 cells. We obtained adipocyte 3T3L-1 cells from ATCC, which were grown to conglomeration in 12 -well culture plates [60,000 cells/well]. Cell differentiation was started 2 days later by incubating cells for 48 hours with 2 $\mathrm{g} / \mathrm{ml}$ insulin, $0.5 \mathrm{mM}$ IBMX, and $0.25 \mathrm{mM}$ dexamethasone in DMEM contain $10 \%$ FBS and $1 \%$ antibiotic antimycotic. The culture medium was discarded and replaced with regular medium containing $2 \mu \mathrm{g} / \mathrm{ml}$ of insulin. Cells were re-fed with normal media for another 2 days.

2.4.1.2. Glucose uptake assay using 3T3L-1 cells. Adipocytes 3T3L-1 cells were washed twice with serum-free DMEM after approximately 9 days after differentiation. The cells were then pre-incubated for 2.5 hours in serum-free Dulbecco's modified Eagle's medium (SF-DMEM) before being aspirated and given 1 $\mathrm{ml}$ of SF-DMEM containing insulin or insulin in addition to the test material. For 60 minutes, the adipocyte cells (3T3L-1 cells) were pretreated with a positive control/test material before being stimulated with (1-100 nM) insulin for 30 minutes. This solution was aspirated, and $1 \mathrm{ml}$ of uptake buffer (phosphate buffered saline, $\mathrm{pH}$ 7.4) was added to each well, containing $0.05 \mathrm{mM}$ 2-deoxyglucose $[0.01 \mu \mathrm{Ci} / \mathrm{ml}$ (U-14C)-2-deoxyglucose]. Cells were wash thrice with ice cold saline phosphate buffer solution, after 10 minutes at $37^{\circ} \mathrm{C}$ and lysed with $0.5 \mathrm{ml}$ of phosphate buffered saline containing $1 \%$ Triton X-100. Liquid scintillation was used to measure glucose uptake.

Note: IBMX and dexamethasone encouraged the cells to uptake triglycerides from the serum

\subsection{Rat Insulin Release in Cell Culture Supernatants Samples}

\subsubsection{Reagent preparation}

i. Wash buffer: 1x working wash buffer solution was prepared by diluting $30 \times$ wash buffer concentration with deionized water.

ii. Standard preparation: standards were serially diluted from 48 to $1.56 \mathrm{mIU} / 1$ using standard diluents.

\subsection{Procedure}

2.6.1. Procedure for loading samples, standards, and blanks into wells

Blank wells: $50 \mu \mathrm{l} /$ well of standard diluent (sample, anti-insulin antibody labeled with biotin, and streptavidin-horseradish peroxidase (HRP) were not added). Add chromogen reagents A and $\mathrm{B}$ and stop solution as per the procedure shown. The steps of operation are the same for blanks, samples, and standards.

Standard well: $50 \mu \mathrm{l}$ of standard solution and $50 \mu \mathrm{l}$ of streptavidinHRP.

Sample wells: Biotin antibody $(10 \mu \mathrm{l})$, sample $(40 \mu \mathrm{l})$, and streptavidin-HRP $(50 \mu \mathrm{l})$. Then the plate was sealed and incubated at $37^{\circ} \mathrm{C}$ for 60 minutes.

After incubation, the plate was washed thrice using $1 \times$ wash buffer by soaking the wells for about 30 seconds between each wash. Any remaining wash buffer was thoroughly removed either by aspiration or blotting the plate on a paper towel.

i. For color development, $50 \mu \mathrm{l}$ of chromogen reagent A was added to each well, followed by $50 \mu \mathrm{l}$ of chromogen reagent $\mathrm{B}$ and incubate for 10 minutes at $37^{\circ} \mathrm{C}$ in dark.

ii. $50 \mu 1$ stop solution to each well was added to stop the reaction.

iii. Absorbance was measured at $450 \mathrm{~nm}$.

\subsection{Hydrolysis Index Analysis}

Two grams of the carbohydrate sample of each item was sliced and crushed in a mortar with pestle with $20 \mathrm{ml}$ of $0.1 \mathrm{M}$ potassium phosphate buffer solution ( $\mathrm{pH}$ 6.9) maintained at $37^{\circ} \mathrm{C}$, and $1 \mathrm{ml}$ of $A$. indicum (L.) extract was added to the mixture. Samples were homogenized at constant speed, followed by washing with $20 \mathrm{ml}$ buffer solution. Following homogenization, ortho-phosphoric acid is used to lower the $\mathrm{pH}$ to 2.5 , followed by $1 \mathrm{ml}$ of trypsin enzyme (Sigma-Aldrich) $(10 \mu \mathrm{g})$. The samples were placed in a $37^{\circ} \mathrm{C}$ stirring water bath for 1 hour to simulate the time that food would be churned in the human stomach. Each sample was then re-buffered to $\mathrm{pH} 6.8$ with $\mathrm{KOH}$, and $2 \mathrm{ml} \alpha$-amylase enzyme (Sigma-Aldrich) $(20 \mu \mathrm{g})$ was added. The whole content of the 
flask was then transferred into dialysis bags, and then immersed in $500 \mathrm{ml}$ buffer solution. The flasks were swirled in a water bath, with $40 \mathrm{ml}$ of the buffer solution was removed every 30 minutes for analysis of the rate carbohydrate hydrolysis from the buffer solution. During the analysis, the volume of the buffer solution was allowed to decrease. The area plotted under the concentrationover-time curve (AUC) was calculated after which the results were displayed on a graph. The hydrolysis index (HI) values were determined by comparing the AUC of the particular food to the AUC of maltose, which served as the reference food. The following equation was used:

$$
\mathrm{GI}=\left(\mathrm{iAUC}_{\text {test food }} / \mathrm{iAUC}_{\text {reference food }}\right) \times 100
$$

$\mathrm{HI}$ of food tested $=$ AUC food tested $\div$ AUC reference food

\subsection{1,1-Diphenyl-2-Picryl Hydrazyl (DPPH) Radical Scavenging Assay}

DPPH assay was carried out as per the method of Ononamadu et al. [28]. Briefly, $75 \mu \mathrm{g} / \mathrm{ml}$ of DPPH solution, various concentrations of the test solution, and high-performance liquid chromatography grade methanol were added to make up $3 \mathrm{ml}$. There are different concentrations tested for the reference standard: $0.5,1.0,1.5,2.0$, and $2.5 \mu \mathrm{g} / \mathrm{ml}$. Then, the reaction mixture is mixed and incubated for 15 minutes at $25^{\circ} \mathrm{C}$. A semi-autoanalyzer is used to measure the absorbance at $590 \mathrm{~nm}$. A control reaction is carried out without the test sample.

\subsection{Molecular Docking Analysis}

The crystal protein data bank (PDB) structure of human peroxisome proliferator-activated receptor gamma (PPAR $\gamma$; PDB ID: 2P4Y) was retrieved from the PDB. Substrate analogue, water molecules, and other crystallographic buffer components were relieved by Molegro Molecular Viewer. For molecular docking, Autodock4 program tools were employed following the Lamarckian genetic algorithm [31]. Khan et al. [32] extracted the most active four known compounds: 1 . syringic acid, 2. methyl caffeate, 3 . methyl trans-p-coumarate, and 4. pinellic acid. Different solvents like petroleum ether extract, methanol extract, chloroform, and ethyl acetate subfractions from $A$. indicum leaves were studied and their cytotoxicity on U87MG human glioblastoma cells same phytoactive compounds were chosen and drawn from the PubChem database, which is listed in Table 5, as well as their molecular interaction with PPAR $\gamma$ was studied [33].

\section{RESULTS AND DISCUSSION}

\subsection{Glucose Uptake Assay Using 3T3L-1 Adipocytes}

PPAR $\gamma$ plays an important role in adipogenesis [34]. Researchers have found that PPAR $\gamma$ affects adipogenesis and glucose uptake independently, and these two factors have important implications for the development of better diabetes drugs. In vitro studies were conducted on the glucose utilization of 3T3L-1 cell lines. Adipocytes and 3T3-L1 cells were supplemented for 48 hours. and the experimental results showed that $100 \mathrm{nM}$ insulin and $50 \mathrm{mM} \mathrm{LiCl}$ glucose uptake showed 3.37 and 3.86-fold stimulation, respectively, when compared to control, whereas the given samples at 200, 400 , and $800 \mu \mathrm{g} / \mathrm{ml}$ showed $1.37,1.62$, and 1.85 fold stimulation, respectively, when compared to control (Fig. 1). The results obtained in the present study clearly demonstrate that $A$. indicum (L.) extract enhances glucose uptake under in vitro conditions (Table 1).

\subsection{Quantification of Insulin Release by ELISA}

Insulin secretion and glucose homeostasis are dependent on pancreatic cell regulation, which is implicated in a range of physiological and pathological situations such as apoptosis, glucotoxicity, autoimmunity, and insulin resistance. A breakdown in glucose homeostasis is caused by permanent damage and pancreatic cell death, which plays a key role in the development of

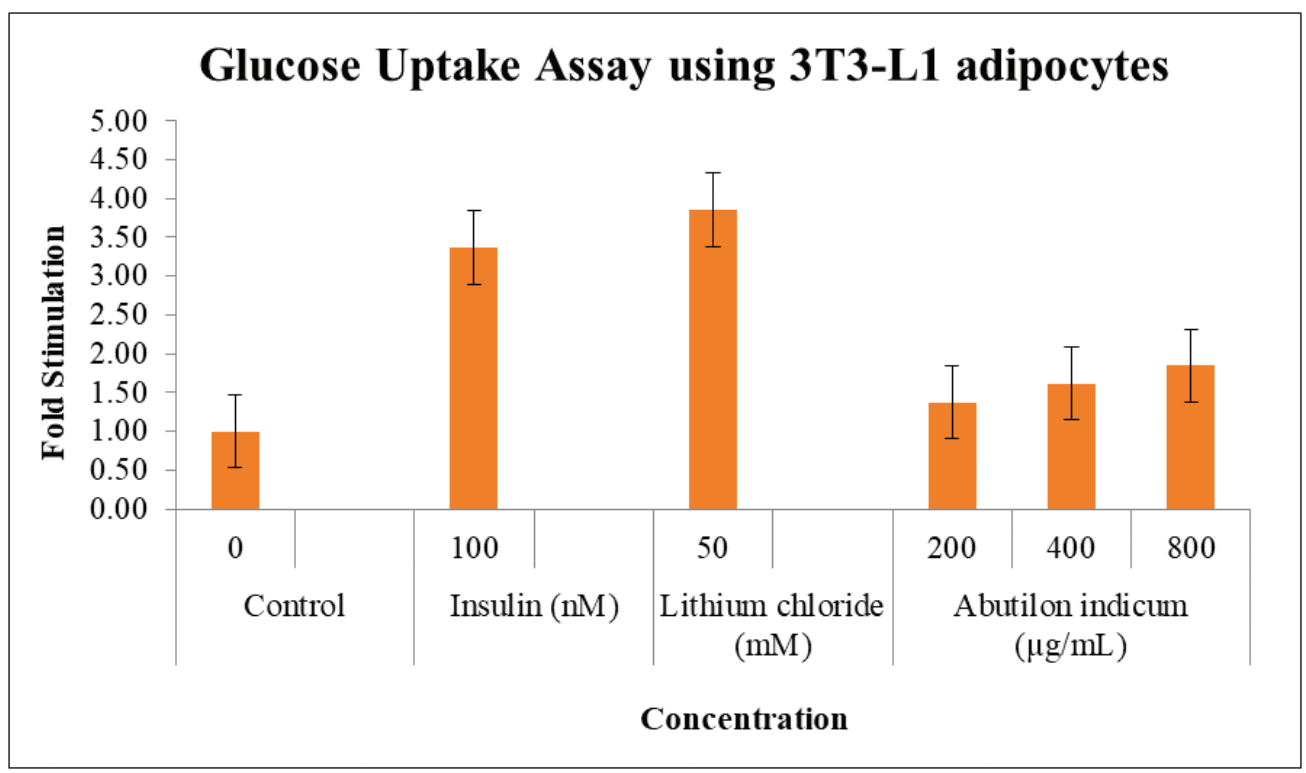

Figure 1: Glucose uptake assay in 3T3L-1 cells. 
diabetes. The RIN-5F pancreatic cell line was used to evaluate the activity of insulin secretion $[35,36]$. The insulin release in RIN$5 \mathrm{f}$ cells treated with various concentrations was quantified by an insulin calibration linear graph (Table 2; Fig. 2). The sample shows a dose-dependent increase in insulin secretion and the highest test concentration of $800 \mu \mathrm{g} / \mathrm{ml}$ showed 2.67 -fold stimulation. Glucose (taken as a positive control) at $5 \mathrm{mM}$, showed 4.67 -fold stimulation (Table 3; Fig. 3)

\subsection{Hydrolysis Index Analysis}

The AUC was calculated for the tested food sample (Fig. 4) along with the control using the trapezoidal rule, and the HI value was estimated by taking the measure of the relationship of the area under the curve of the tested food sample to the area under the curve of the maltose taken as the reference food (Table 4). Glycemic load (GL), assessing the total glycemic of diet which proved to be crucial in the epidemiological studies, was also estimated by taking account of the product of dietary GI [37] and the carbohydrate content of the test food sample. The HI value of tested sample was found to be 53.30 and the GL was 17.48. However, the GI value of white rice is reported in the GI and load guide to be 73 [38], which suggests that the reproducibility of the data is precise in accordance with the test sample.

\subsection{DPPH Radical Scavenging Assay}

DPPH is a stable free radical with purple color and the antioxidants reduce the DPPH colorless compound which is measured at an absorbance of $590 \mathrm{~nm}$. In the DPPH assay, the sample showed a dose-dependent DPPH radical scavenging activity with $\mathrm{IC}_{50}$ value of $99.12 \mu \mathrm{g} / \mathrm{ml}$ when compared to standard quercetin with an $\mathrm{IC}_{50}$ value of $1.7 \mu \mathrm{g} / \mathrm{ml}$ (Table 5; Fig. 5).

Calculating percentage growth inhibition is as follows: \% inhibition $=\left(\mathrm{OD}_{\text {control }}-\mathrm{OD}_{\text {sample }}\right) / \mathrm{OD}_{\text {control }} \times 100$

Table 2: Insulin calibration analysis.

\begin{tabular}{|c|c|c|}
\hline & Conc. $\mu \mathrm{IU} / \mathrm{ml}$ & OD at $450 \mathrm{~nm}$ \\
\hline Control & 0 & 0.088 \\
\hline \multirow{6}{*}{ Calibrant } & 4.69 & 0.113 \\
\hline & 9.38 & 0.1236 \\
\hline & 18.75 & 0.1366 \\
\hline & 37.5 & 0.1857 \\
\hline & 75 & 0.2566 \\
\hline & 150 & 0.3916 \\
\hline
\end{tabular}

Table 1: Glucose uptake assay in 3T3L-1 cells.

\begin{tabular}{lcccc} 
Sample & Conc. & Mean counts per minute (CPM) & Fold stimulation & SEM \\
Control & 0 & 4,296 & 1.00 & 296 \\
Insulin $(\mathrm{nM})$ & 100 & 14,465 & 3.37 & 1,097 \\
Lithium chloride $(\mathrm{mM})$ & 50 & 16,576 & 3.86 & 1,402 \\
& 200 & 5,904 & 1.37 & 554 \\
A. indicum $(\mu \mathrm{g} / \mathrm{ml})$ & 400 & 6,941 & 1.62 & 1,521 \\
& 800 & 7,938 & 1.85 & 1,221 \\
\hline
\end{tabular}

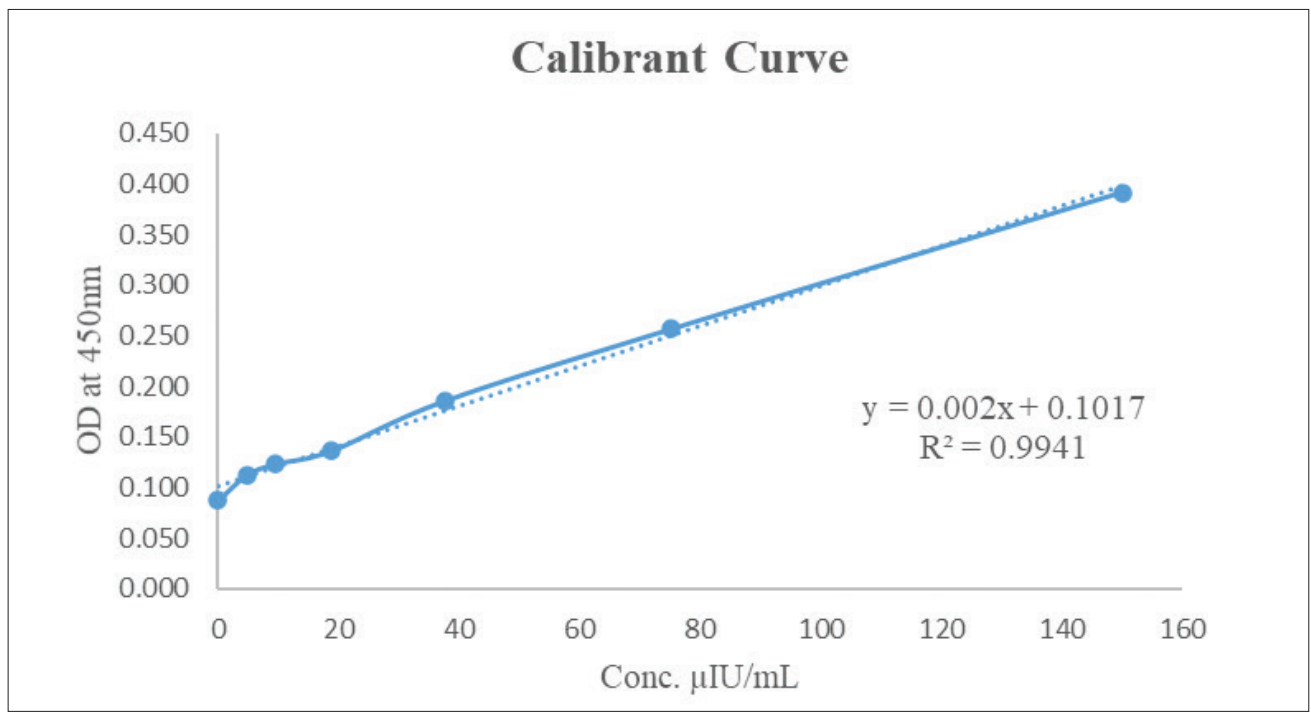

Figure 2: Insulin calibration graph. 
Table 3: Quantification of insulin release in RIN-5f cells treated with $A$. indicum.

$\begin{array}{lcccc}\text { Sample } & \text { Test conc. }(\boldsymbol{\mu g} / \mathbf{m l}) & \text { OD at } \mathbf{4 5 0} \mathbf{~ n m} & \text { Insulin conc. }(\mathbf{m I U} / \mathbf{l}) & \text { Fold stimulation } \\ & 0 & 0.1029 & 0.60 & 1.00 \\ & 50 & 0.1032 & 0.75 & 1.25 \\ \text { A. indicum } & 100 & 0.1036 & 0.95 & 1.58 \\ & 200 & 0.1039 & 1.10 & 1.83 \\ & 400 & 0.1044 & 1.35 & 2.25 \\ \text { Glucose (positive } & 800 & 0.1049 & 1.60 & 2.67 \\ \text { control) } & \text { Glucose (positive control) } & 0.1073 & 2.80 & 4.67\end{array}$

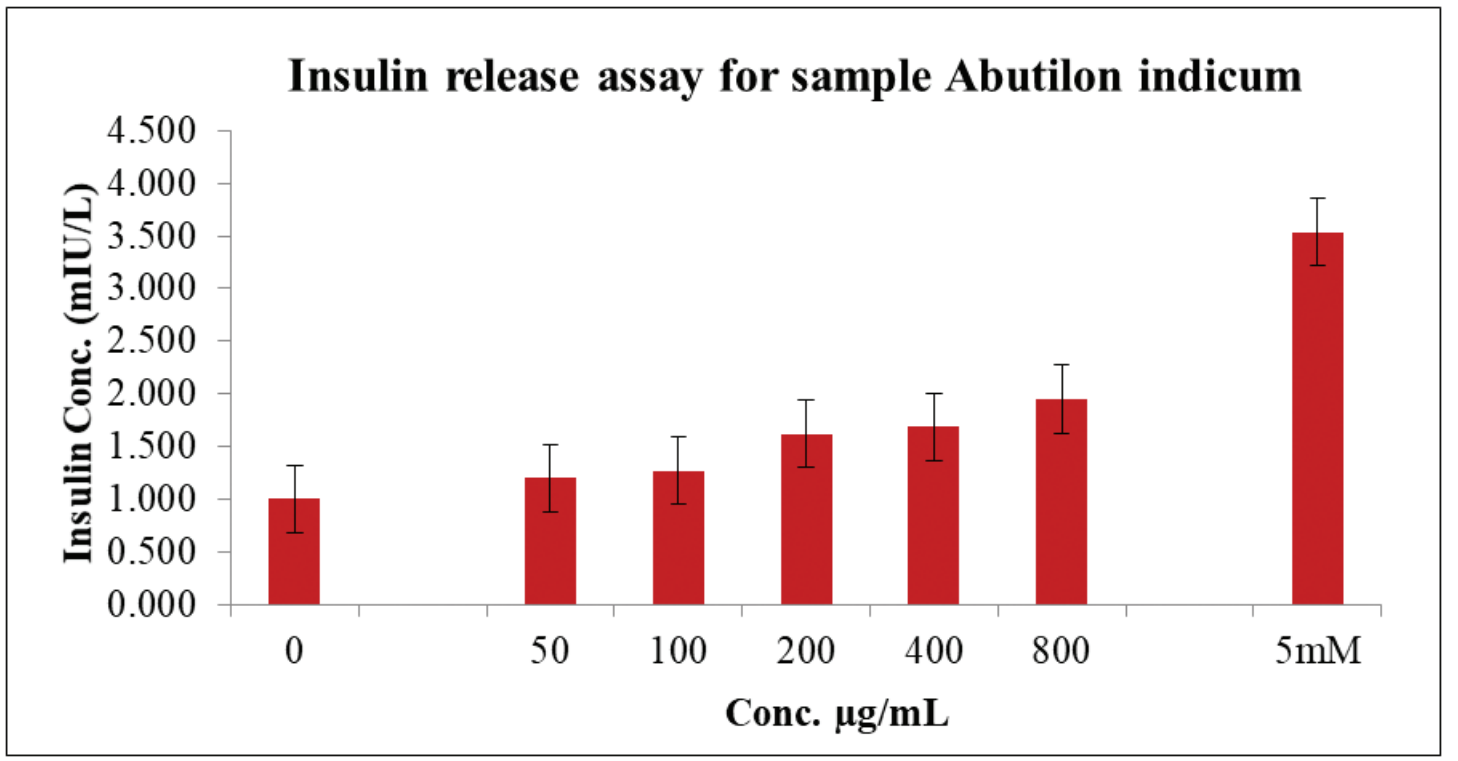

Figure 3: Representation of the quantification of insulin release in RIN-5f cells treated with A. indicum.

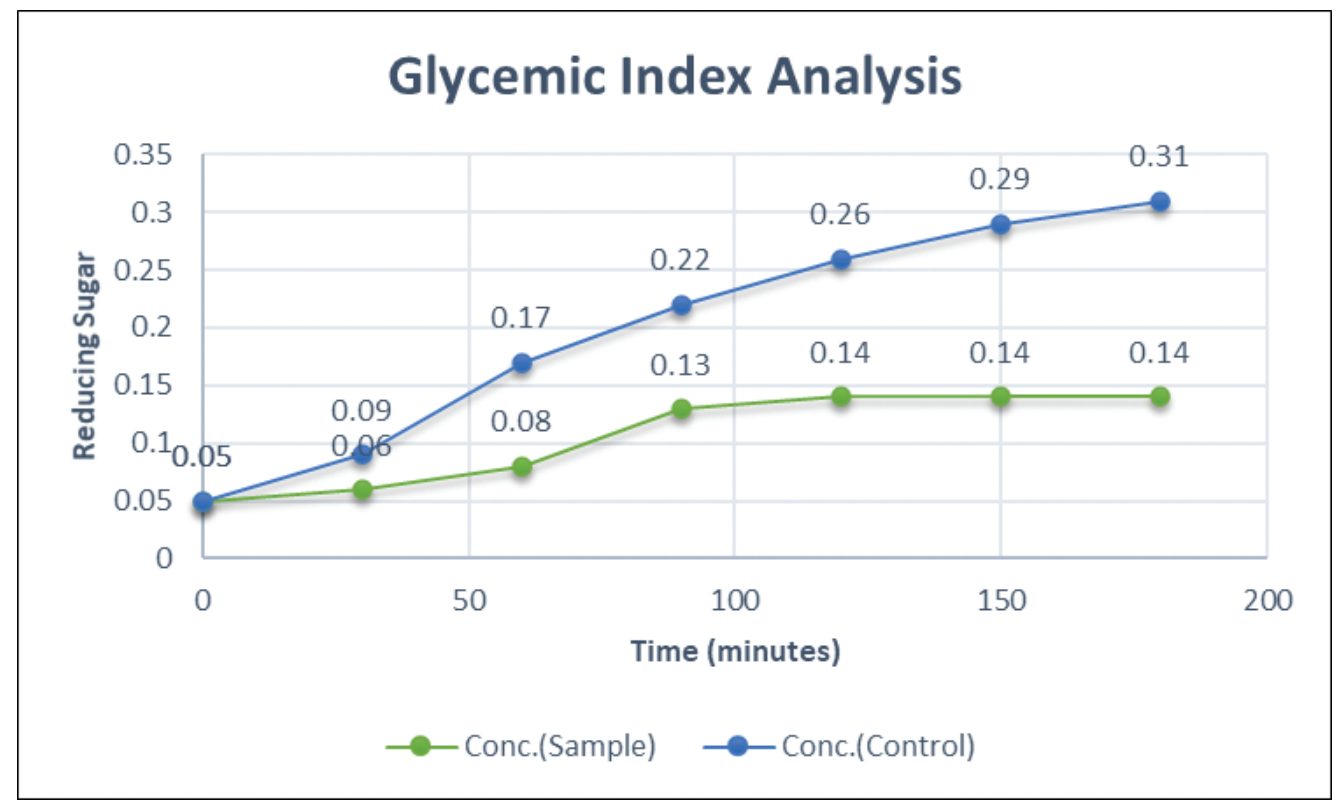

Figure 4: Hydrolytic variation in the concentration of the reducing sugar with respect to time. 

inhibitory effect of Abutilon indicum (L.) extract 2022;10(01):145-156

Table 4: AUC, HI, and GL.

$\begin{array}{ccccc}\text { Time (minutes) } & \text { Conc. }(\mathbf{u g} / \mathbf{m l})(\text { Sample) } & \text { Conc. }(\mathbf{u g} / \mathbf{m l})(\text { Control }) & \text { AUC }(\text { Sample) } & \text { AUC (Control) } \\ 0 & 0.05 & 0.05 & - & - \\ 30 & 0.06 & 0.09 & 1.65 & 2.1 \\ 60 & 0.08 & 0.17 & 2.1 & 3.15 \\ 90 & 0.13 & 0.22 & 3.15 & 4.35 \\ 120 & 0.14 & 0.26 & 4.05 & 5.25 \\ 150 & 0.14 & 0.29 & 4.2 & 5.55 \\ 180 & 0.14 & 0.31 & 4.2 & 5.85 \\ & \text { Total area under the curve } & & \mathbf{1 9 . 3 5} & \mathbf{3 6 . 3 0} \\ & \mathbf{H I}^{\mathrm{a}} & & \mathbf{5 3 . 3 0} & \mathbf{1 0 0} \\ \end{array}$

${ }^{\mathrm{a}}($ AUC Sample/AUC Control) $\times 100$

${ }^{\mathrm{b}}$ Glycemic index $(\mathrm{GI}) *$ Carbohydrate content of the sample)/100.

Table 5: DPPH radical scavenging assay.

\begin{tabular}{|c|c|c|c|c|}
\hline Sample name & Conc. $(\mu \mathrm{g} / \mathrm{ml})$ & $\begin{array}{c}\text { Absorbance (590 } \\
\mathbf{n m})\end{array}$ & $\%$ inhibition & $\mathrm{IC}_{50}(\mu \mathrm{g} / \mathrm{ml})$ \\
\hline Control & 0 & 0.252 & 0 & 0 \\
\hline \multirow[t]{7}{*}{ Quercetin } & 0.3125 & 0.241 & 4.2063492 & \multirow{7}{*}{1.70} \\
\hline & 0.625 & 0.194 & 23.095238 & \\
\hline & 1.25 & 0.197 & 21.785714 & \\
\hline & 2.5 & 0.151 & 40.238095 & \\
\hline & 5 & 0.093 & 63.293651 & \\
\hline & 10 & 0.094 & 62.698413 & \\
\hline & 20.000 & 0.081 & 67.857143 & \\
\hline \multirow[t]{6}{*}{ Sample } & 3.125 & 0.242 & 3.8492063 & \multirow{6}{*}{99.12} \\
\hline & 6.25 & 0.234 & 7.2222222 & \\
\hline & 12.5 & 0.216 & 14.484127 & \\
\hline & 25 & 0.196 & 22.142857 & \\
\hline & 50 & 0.148 & 41.269841 & \\
\hline & 100 & 0.103 & 59.325397 & \\
\hline
\end{tabular}

\subsection{Molecular Docking Analysis}

Khan et al. [32] studied the different solvent extracts of $A$ indicum leaves for cytotoxicity on U87MG human glioblastoma cells and the most active AIM-C. The syringic acid, methyl trans-p-coumarate, pinellic acid, and methyl caffeate fractions were repeatedly chromatographed to produce four recognized compounds: methyl trans-p-coumarate, pinellic acid, methyl caffeate, and syringic acid. An experiment of chemical 1-4 on cell viability against U87MG cells revealed that chemical 2 had the highest $\mathrm{IC}_{50}$ value $(8.2 \mathrm{mg} / \mathrm{ml})$, while the others had significantly lower activity. In normal human cells (HEK-293), compounds 1-4 were shown to be non-toxic. These compounds were studied along with the antidiabetic drug molecule TZDs to study their molecular interaction. The molecular interaction between PPAR $\gamma$ with A. syringic acid, B. methyl caffeate, C. pinellic acid, D. methyl transp-coumarate, and E. TZDs is shown in Table 6 and Figure 6.
Adipogenesis is a complex and coordinated process which begins with the upregulation of two early transcription factors, cytosine-cytosine-adenosine-adenosine-thymidine/enhancerbinding protein beta $(\mathrm{C} / \mathrm{EBP})$ and $\mathrm{C} / \mathrm{EBP}$, which then induces the expression of PPAR $\gamma$, the master gene in adipogenesis, which increases the expression of proteins associated with the adipocyte phenotype. 3T3L-1 fibroblasts are precursor cells used as a model to study adipogenesis [39]. A combination of insulin, dexamethasone, and methylisobutylxanthine is used to promote preadipocyte differentiation. After a few days, the cells grew spherically and began to collect lipid droplets, and 7-10 days after induction, they reached final differentiation.

Although antidiabetic efficacy has been demonstrated in several studies, a broad usage of PPAR $\gamma$ agonists has been limited due to severe cardiovascular consequences. To address this issue, 
A.

\section{DPPH Radical scavenging activity (Quercetin)}

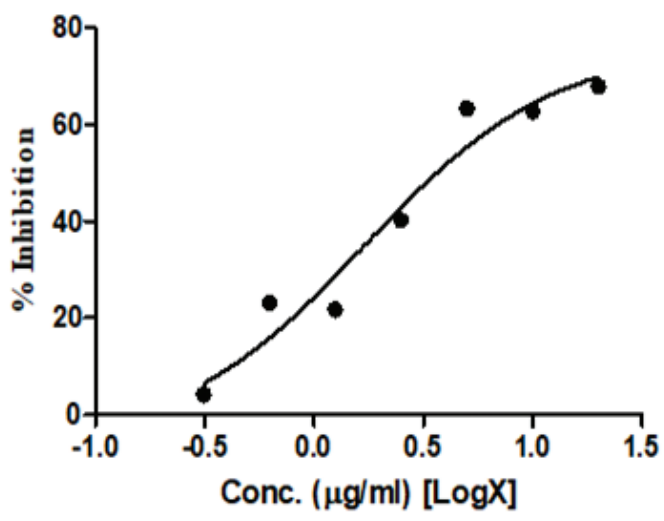

B.

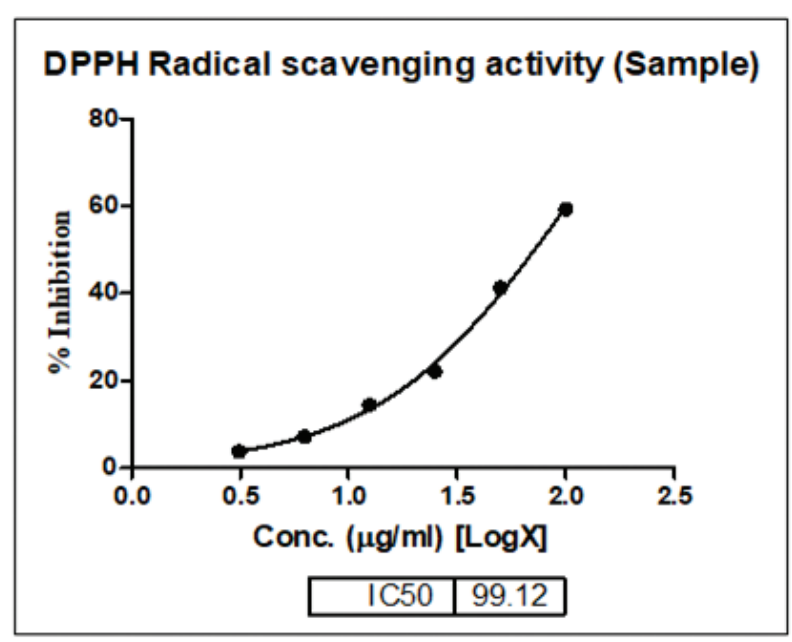

Figure 5: A. DPPH radical scavenging activity (quercetin). B. DPPH radical scavenging activity (sample).

Table 6: Molecular interaction between PPAR $\gamma$ with A. syringic acid, B. methyl caffeate, C. pinellic acid, D. methyl trans-pcoumarate, and E. TZDs and the number of hydrogen bonds, hydrogen bond interactions, and energy.

\begin{tabular}{llcll} 
Ligand name & PubChem Id & No. of hydrogen bonds & Hydrogen bond interaction & Energy \\
Syringic acid & 10742 & 2 & ARG288:HE, SER342:HN & -3.9 \\
Methyl caffeate & 689075 & 3 & GLU343:OE2, ARG288:HH, ARG288:HH & -4.49 \\
Pinellic acid & 9858729 & 2 & THR229, LEU 340 & -2.62 \\
Methyl trans-p-coumarate & 5319562 & 2 & GLU295:OE1, GLU343:HN & -5.44 \\
TZDs & 50944073 & 2 & GLN286:OE1, SER289:HG & -7.62 \\
\hline
\end{tabular}

researchers discovered selective PPAR $\gamma$ modulators with antidiabetic effectiveness equivalent to full agonists but with better tolerability in preclinical animals [40]. In humans and animals, pharmacological agonists for the nuclear receptor PPAR $\gamma$ improve glucose excretion in a number of insulin-resistant conditions. The exact processes through which PPAR $\gamma$ activation leads to enhanced glucose absorption in metabolically active cells are not known. Notably, several new, synthetic PPAR $\gamma$ ligands appeared to block thiazolidinedione-induced adipogenesis; however, further research is needed. TZDs are a novel family of drugs used to treat type 2 diabetes $[41,42]$.

They stimulate adipogenesis and fatty acid absorption via binding to PPAR $\gamma$ in adipocytes (in peripheral but not visceral fat). The medicines enhance insulin sensitivity by lowering circulating fatty acid concentrations and lipid availability in the liver and muscle [43].

Cardiovascular disease is primarily caused by two prevalent risk factors: aging and DM [44].

The prevalence of diabetes has tended to prevail despite a vast number of developments and discoveries of newer medicines to cure or avoid the disease. Persistent hyperglycemia damages different organs over time, especially those that require insulin for glucose uptake. Many plants have been used to cure DM over the years. A notable discovery of $A$. indicum extract is that it has significant insulin-like characteristics, as demonstrated by increased glucose absorption in the diaphragm, which represents muscle cells and is the primary location of insulin-stimulated glucose disposal. GLUT4 is the most common glucose transporter found in insulin-responsive tissues including skeletal muscle and adipose tissue $[45,46]$.

Glucose transporters are mainly responsible for the uptake of glucose by insulin-mediated cells, as the insulin level decreases and glucose transporters move across the membrane into intracellular pools for the purpose of storage and this process is recycled [47,48]. A vital aspect of maintaining whole body glucose homeostasis is insulin's ability to stimulate glucose uptake into muscle and adipose tissue [49]. Insulin signaling pathway is always associated with insulin resistance which is crucially found in the development of DM (type 2 diabetes) as they majorly contribute in the role of type 2 diabetes mellitus. At one perfect point, insulin receptors (IRs) will proliferate through multiple pathways. Insulin released into the blood stream by cells in which high level of glucose detected through beta cells present in pancreas. This processes insulin transport across the blood and binds specifically to the receptors which are embedded in the cell membrane such as brain cells, liver, muscle cells, adipose, etc. Diets with high glycemic reactions, which cause a high increment in blood glucose, have been correlated with expanded danger 


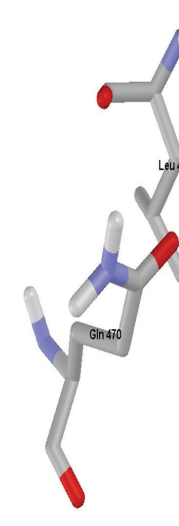

A. syringic acid

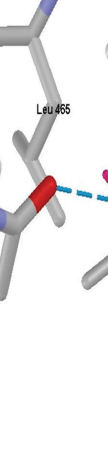

\section{r}

nter<smiles>[C]1C=C2[CH]C1=C2</smiles>

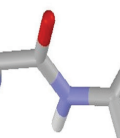

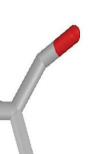

B. Methyl caffeate

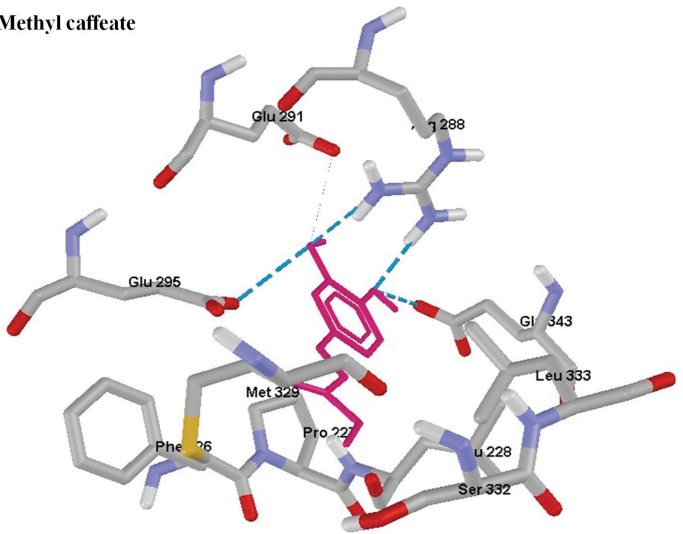

C. Pinellic acid
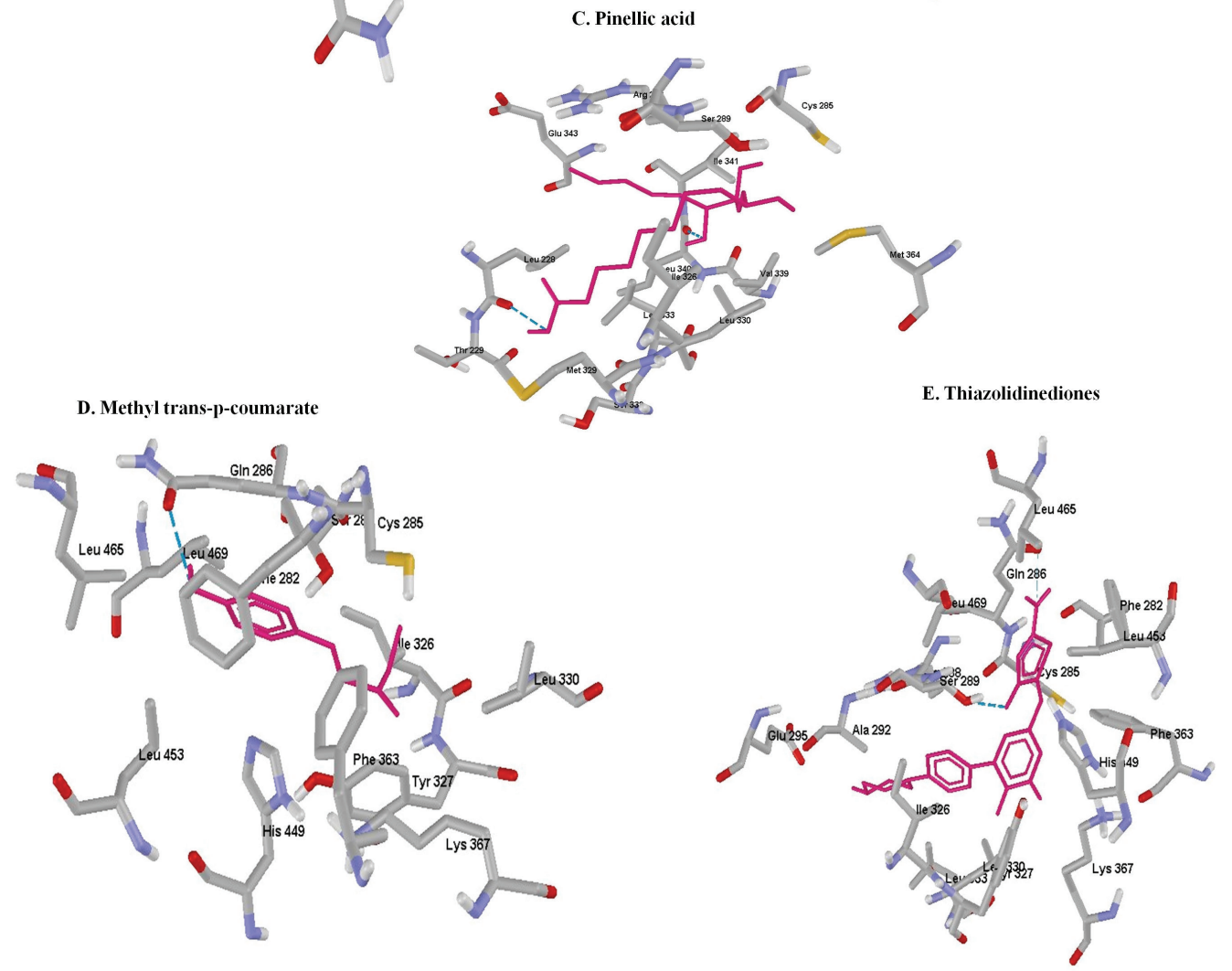

Figure 6: Molecular interaction between PPAR $\gamma$ with A. syringic acid, B. methyl caffeate, C. pinellic acid, D. methyl trans-p-coumarate, and E. TZDs.

of type II diabetes, chronic diseases, and cardiovascular illness, including stoutness and specific sorts of malignancy [50,51]. Diabetes is regulated by AGE receptors glyoxalase 1, tumor necrosis factor, chronic unreliable stress, reactive oxygen species, and other modulators like inflammation cytokines [52].

The present investigation indicated that the test sample exhibited lower glycemic response in correspondence to the control sample suggesting it to be the low GI food and inferred to be recommended for the people ailing with type 2 diabetes, as per the standardization to the WHO. Foods with $\mathrm{GI}<55$ are considered to be low GI foods; GI from 56 to 69 as medium GI foods; and GI 70 are high GI foods [53,54]. The antioxidant properties of A. indicum leaf extract on DNA damage and peripheral blood lymphocytes
(PBLs) in combating oxidative stress, as well as radiation-induced DNA damage protection and oxidative stress quenching effects of A. indicum ethanolic leaf extract (EEAI) on human PBLs were investigated. The effects of EEAI on human PBLs revealed that the extract at $150 \mathrm{~g} / \mathrm{ml}$ decreased the cytotoxicity of hydrogen peroxide by more than half [55]. Researchers have identified phytochemicals with antidiabetic potential, as well as how to inhibit the disease.

According to studies, carbohydrate counting may be the best technique for people with diabetes to manage their blood glucose levels in the body. There have been some medical studies indicating that a low-GI diet may help individuals with diabetes control their blood glucose levels, regardless of the fact that the observed effects 
could also be attributed to the low-calorie, high-fiber content of the eating regimens recommended in the investigation.

\section{CONCLUSION}

This research on the health effects of traditional plant-based foods will benefit the treatment of various diseases. In conclusion, the present research work explains the potentiating effects of $A$. indicum methanolic leaf on glucose uptake in 3T3L-1 adipocytes were mediated via PPAR $\gamma$ through in vitro as well molecular docking studies. We have studied that PPAR $\gamma$ agonists potentiate basal and insulin-stimulated glucose uptake in 3T3L-1 adipocytes. In cells expressing 3T3L-1 adipocytes that suppress adipogenesis, the potentiation of glucose uptake is maintained, indicating that downstream effects to PPAR $\gamma$ activation are selective. Drugs that increase insulin sensitivity without increasing fat formation might be produced if such specific regulation of receptor activity could be carried out using PPAR $\gamma$. Moreover, RIN5F cell lines for insulin secretion shown a dose-dependent increase in insulin secretion and the highest test concentration of 800 $\mu \mathrm{g} / \mathrm{ml}$ showed 2.67-fold stimulation. Also, the HI value was found to be 53.30 and GL was $17.48 \mu \mathrm{g} / \mathrm{ml}$. Because insulin resistance has been related to the progression of type $2 \mathrm{DM}$, natural phytochemicals that activate $5^{\prime}$ adenosine monophosphate-activated protein kinase activation should have a substantial therapeutic influence on the diabetes. These results suggest that $A$. indicum (L.) is potential indicator for sensitizing insulin secretion and strongly inhibits the release of glucagon which can be used as a safe method or supplement treatment strategy to control diabetes. The derived products may be an important source of nutrition and therapy as well development of new pharmaceuticals to treat DM.

\section{AUTHOR CONTRIBUTIONS}

All authors made substantial contributions to conception and design, acquisition of data, or analysis and interpretation of data; took part in drafting the article or revising it critically for important intellectual content; agreed to submit to the current journal; gave final approval of the version to be published; and agree to be accountable for all aspects of the work. All the authors are eligible to be an author as per the international committee of medical journal editors (ICMJE) requirements/guidelines.

\section{FUNDING}

There is no funding to report.

\section{CONFLICTS OF INTEREST}

The authors report no financial or any other conflicts of interest in this work.

\section{ETHICAL APPROVALS}

This study does not involve experiments on animals or human subjects.

\section{PUBLISHER'S NOTE}

This journal remains neutral with regard to jurisdictional claims in published institutional affiliation.

\section{REFERENCES}

1. Cade WT. Diabetes-related microvascular and macrovascular diseases in the physical therapy setting. Phys Ther 2008;88(11):1322-35.

2. Li S, Wang J, Zhang B, Li X, Liu Y. Diabetes mellitus and causespecific mortality: a population-based study. Diabetes Metab J 2019;43(3):319-41.

3. Harris-Hayes M, Schootman M, Schootman JC, Hastings MK. The role of physical therapists in fighting the type 2 diabetes epidemic. J Orthop Sports Phys Ther 2020;50(1):5-16; doi:10.2519/ jospt.2020.9154.

4. El-Hawary SS, Mohammed R, El-Din ME, Hassan HM, Ali ZY, Rateb $\mathrm{ME}$, et al. Comparative phytochemical analysis of five Egyptian strawberry cultivars (Fragaria X ananassa Duch.) and antidiabetic potential of festival and red merlin cultivars. RSC Adv 2021;11:16755; doi:10.1039/d0ra10748d

5. Smith JD, Hou T, Ludwig DS, Rimm EB, Willett W, Hu FB, et al Changes in intake of protein foods, carbohydrate amount 56, 35-46. and quality, and long-term weight change: results from 3 prospective cohorts. Am J Clin Nutr 2015;101(6):1216-24.

5. Wasana KGP, Attanayake AP, Jayatilaka KAPW, Weerarathna TP Antidiabetic activity of widely used medicinal plants in the Sri Lankan traditional healthcare system: new insight to medicinal flora in Sri Lanka. Evid Based Complement Alternat Med 2021;2021(12):Article ID 6644004; doi:10.1155/2021/6644004.

6. Suresh Y, Rajasekar G, Lavanya T, Lakshminarsimhulu B, Reddy KS, Reddy SR. Antioxidant and antidiabetic properties of isolated fractions from methanolic extract derived from the whole plant of Cleome viscosa L. Future J Pharm Sci 2020;6:103; doi:10.1186/s43094-02000122-1

7. Idakwoji PA, Joshua PE, Asomadu RO, Njoku OU, Nwodo OFC Antidiabetic activity, phytochemical and proximate compositions of different extracts of Tephrosia bracteolata leaves. Asian J Plant Sci 2021;20:291-9. Available via https://scialert.net/ abstract/?doi=ajps.2021.291.299

8. Lee J, Noh S, Lim S, Kim B. plant extracts for type 2 diabetes: from traditional medicine to modern drug discovery. Antioxidants 2021;10:81. doi:10.3390/ antiox10010081.

9. Lopez AD, Mathers CD. Measuring the global burden of disease and epidemiological transitions: 2002-2030. Ann Trop Med Parasitol 2006;100(5-6):481-99.

10. Prasad LV. Traditional medicine in Asia. In: Chaudhury RR, Rafei UM (eds.). Indian system of medicine and homoeopathy, WHO- Regional Office for South East Asia, New Delhi, India, pp 283-286, 2002.

11. Roglic G. WHO global report on diabetes: a summary. Int J NonCommun Dis 2016;1:3-8. Available via https://www.ijncd.org/text. asp?2016/1/1/3/184853

12. Krishnamoorthy K, Subramaniam P. Phytochemical profiling of leaf, stem, and tuber parts of Solena amplexicaulis (Lam.) Gandhi using GC-MS. Int Scholarly Res Notices 2014;2014:13; doi:10.1155/2014/567409.

13. Vivekraj P, Vinotha S, Vijayan A, Gideon VA. Preliminary phytochemical screening and GC-MS analysis of methanolic extract of Turnera subulata Smith (Passifloraceae). J Phytopharmacol 2017;6(2):174-7.

14. Rukshana MS, Doss A, Kumari PR. Phytochemical screening and GC-MS analysis of leaf extract of Pergularia daemia (Forssk) Chiov. Asian J Plant Sci Res 2017;7(1):9-15.

15. Ramana Murty Kadali SLDV, Das MC, Vijayaraghavan R, Shanmukha I. In vitro evaluation of antidiabetic activity of aqueous and ethanolic leaves extracts of Chloroxylon swietenia. Natl J Physiol Pharm Pharmacol 2017;7(5):486-90.

16. Shettar AK, Vedamurthy AB. Studies on in vitro antidiabetic activities of Hopea ponga and Vitex leucoxylon. Int J Pharm Pharm Sci 2017;9(2):263-67. 
17. Kong M, Xie K, Lv M, Li J, Yao J, Yan K, et al. Anti-inflammatory phytochemicals for the treatment of diabetes and its complications: lessons learned and future promise. Biomed Pharmacother 2021;133:110975; doi:10.1016/j.biopha.2020.110975.

18. Saeedi P, Petersohn I, Salpea P, Malanda B, Karuranga S, Unwin N, et al. Global and regional diabetes prevalence estimates for 2019 and projections for 2030 and 2045: Results from the International Diabetes Federation Diabetes Atlas. 9th edition. Diabetes Res Clin Pract 2019;157:107843.

19. Rahman S, Jan G, Jan FG, Rahim HU. Phytochemical screening and antidiabetic, antihyperlipidemic, and antioxidant effects of Leptopus cordifolius decne. In Diabetic Mice. Front Pharmacol 2021;12:643242; doi:10.3389/fphar.2021.643242.

20. Sapkota BK, Khadayat K, Adhikari B, Poudel DK, Niraula P, Budhathoki $\mathrm{P}$, et al. Phytochemical analysis, antidiabetic potential and in-silico evaluation of some medicinal plants. Pharmacogn Res 2021;13(4). Available via http://www.phcogres.com/ article/2021/13/4/105530pres134x-3

21. Abdul MM, Sarker AA, Saiful IM, Muniruddin A. Cytotoxic and antimicrobial activity of the crude extract of Abutilon indicum. Int J Pharmacogn Phytochem Res 2010;(2)1:1-4.

22. Guru A, Issac PK, Velayutham M, Saraswathi NT, Arshad A, Arockiaraj J. Molecular mechanism of down-regulating adipogenic transcription factors in 3T3-L1 adipocyte cells by bioactive anti-adipogenic compounds. Mol Biol Rep 2021;48(1):743-61; doi:10.1007/s11033020-06036-8

23. Murugan DD, Balan D, Wong PF. Adipogenesis and therapeutic potentials of antiobesogenic phytochemicals: insights from preclinical studies. Phytother Res 2021. doi:10.1002/ptr.7205.

24. Idowu JS, Maryna VDV, Trevor K, Graeme B. In Vitro antidiabetic activity and mechanism of action of Brachylaena elliptica (Thunb.) DC. Evid Based Complement Alternat Med 2018;13:Article ID 4170372. doi: $10.1155 / 2018 / 4170372$.

25. Alessi DR, Downes CP. The role of PI 3-kinase in insulin action. Biochimic Biophys Acta 1998; 436(1-2):151-64.

26. Khazaei M, Pazhouhi M. Protective effect of hydroalcoholic extracts of Trifolium pratense L. on pancreatic $\beta$ cell line (RIN-5F) against cytotoxicty of streptozotocin. Res Pharm Sci 2018;13(4):324-31; doi:10.4103/1735-5362.235159.

27. Ononamadu CJ, Alhassan AJ, Imam AA, Ibrahim A, Ihegboro GO, et al. In vitro and in vivo anti-diabetic and anti-oxidant activities of methanolic leaf extracts of Ocimum canum. Caspian J Intern Med 2019;10(2):162-75; doi:10.22088/cjim.10.2.162.

28. Park C, Pagnini F, Langer, E. Glucose metabolism responds to perceived sugar intake more than actual sugar intake. Sci Rep 2020;10:15633; doi:10.1038/s41598-020-72501-w.

29. Goodsell DS, Morris GM, Olson AJ. Automated docking of flexible ligands: applications of AutoDock. J Mol Recognit 1996;9:1-5.

30. Khan RS, Senthi M, Rao PC, Basha A, Alvala M, Tummuri D, et al. Cytotoxic constituents of Abutilon indicum leaves against U87MG human glioblastoma cells. Nat Prod Res 2014;29:11; doi:10.1080/147 86419.2014.976643

31. Tamori Y, Masugi J, Nishino N, Kasuga M. Role of peroxisome proliferator-activated receptor-gamma in maintenance of the characteristics of mature 3T3-L1 adipocytes. Diabetes 2002;51(7):2045-55; doi:10.2337/diabetes.51.7.2045.

32. Subash-Babu P, Ignacimuthu S, Alshatwi AA. Nymphayol increases glucose-stimulated insulin secretion by RIN-5F cells and GLUT4mediated insulin sensitization in type 2 diabetic rat liver. Chem Biol Interact 2015;226:72-81; doi:10.1016/j.cbi.2014.12.011.

33. Alshatwi AA, Subash-Babu P. Aloe-emodin protects RIN-5F (pancreatic $\beta$-cell) cell from glucotoxicity via regulation of proinflammatory cytokine and downregulation of bax and caspase 3 . Biomol Ther 2016;24(1):49-56; doi:10.4062/biomolther.2015.056.
34. Jenkins DJ, Wolever TM, Taylor RH, Barker H, Fielden H, Baldwin $\mathrm{JM}$, et al. Glycemic index of foods: a physiological basis for carbohydrate exchange. Am J Clin Nutr 1981;34(3):362-6.

35. Gabrielli M, Romero DG, Martini CN, Raiger Iustman LJ, Vila MDC. MCAM knockdown impairs PPAR $\gamma$ expression and 3T3-L1 fibroblasts differentiation to adipocytes. Mol Cell Biochem 2018;448(1-2):299 309; doi:10.1007/s11010-018-3334-8.

36. Kim SH, Shin EJ, Kim ED, Bayaraa T, Frost SC, Hyun CK. Berberine activates GLUT1-mediated glucose uptake in 3T3-L1 adipocytes. Biol Pharm Bull 2007;30(11):2120-5; doi:10.1248/bpb.30.2120.

37. Greenfield JR, Chisholm DJ, Endocrinology DO. Thiazolidinediones - mechanisms of action. Aust Prescr 2004;27:67-70; doi:10.18773/ austprescr.2004.059.

38. Steenkamp G, Delport L. The South African glycemic index and load guide. 4th edition, 2005.

39. Ida, Y., Watanabe, M., Ohguro, H., \& Hikage, F. (2021). Simultaneous Use of ROCK Inhibitors and EP2 Agonists Induces Unexpected Effects on Adipogenesis and the Physical Properties of 3T3-L1 Preadipocytes. Int J Mol Sci 2021;22(9):4648. doi:10.3390/ijms22094648.

40. Chawla R, Madhu SV, Makkar BM, Ghosh S, Saboo B, Kalra S. RSSDI-ESI clinical practice recommendations for the management of type 2 diabetes mellitus. Indian J Endocrinol Metab 2020;24(4):376. doi:10.4103/ijem.IJEM_225_20.

41. Muruganandan S, Srinivasan K, Gupta S, Gupta PK, Lal J. Effect of mangiferin on hyperglycemia and atherogenicity in streptozotocin diabetic rats. J Ethnopharmacol 2005;97(3):497-501.

42. Chia CW, Egan JM, Ferrucci L. Age-related changes in glucose metabolism, hyperglycemia, and cardiovascular risk. Circ Res 2018; 23(7):886-904. doi:10.1161/CIRCRESAHA.118.312806.

43. Nawaz A, Hasham MA, Rizvi A, Iftikhar M, Butt AM, Minhas $\mathrm{K}$. Knowledge of insulin practices in adult diabetic patients: a crosssectional survey-based study in a specialized diabetic center of a Tertiary Care Hospital. Endocrinol Diabetes Res 2021;7:5. Available via https://www.scitechnol.com/peer-review/sentiments-about-theenvironment-fMCo.pdf

44. Shepherd PR, Kahn BB. Glucose transporters and insulin action-implications for insulin resistance and diabetes mellitus. N Engl J Med 1999;341(4):248-57.

45. Sasaki-Suzuki N, Arai K, Ogata T, Kasahara K, Sakoda H. et al. Growth hormone inhibition of glucose uptake in adipocytes occurs without affecting GLUT4 translocation through an insulin receptor substrate-2-phosphatidylinositol 3-kinase-dependent pathway. J Biol Chem 2009;284(10):6061-70.

46. Chadt A, Al-Hasani H. Glucose transporters in adipose tissue, liver, and skeletal muscle in metabolic health and disease. Pflugers Arch Eur J Physiol 2020;472:1273-1298; doi:10.1007/s00424-020-02417-x

47. Leney SE, Tavare JM. The molecular basis of insulin-stimulated glucose uptake: signalling, trafficking and potential drug targets. J Endocrinol 2009;203:1-18; doi:10.1677/JOE-09-0037.

48. Lizák B, Szarka A, Kim Y, Choi KS, Németh CE, Marcolongo P, et al. Glucose transport and transporters in the endomembranes. J Mol Sci 2019;20(23):5898; doi:10.3390/ijms20235898.

49. Pereira MJ, Palming J, Rizell M, Aureliano M, Carvalho E, Svensson MK, et al. mTOR inhibition with rapamycin causes impaired insulin signalling and glucose uptake in human subcutaneous and omental adipocytes. Mol Cell Endocrinol 2012;355(1):96-105.

50. Parveen A, Sultana R, Lee SM, Kim TH, Kim SY. Phytochemicals against anti-diabetic complications: targeting the advanced glycation end product signaling pathway. Arch Pharm Res 2021;44:378-401. doi:10.1007/s12272-021-01323-9.

51. Juanola-Falgarona M, Salas-Salvado J, Ibarrola-Jurado N, RabassaSoler A, Diaz-Lopez A, Guasch-Ferre M, et al. Effect of the glycemic index of the diet on weight loss, modulation of satiety, inflammation, 
and other metabolic risk factors: a randomized controlled trial. Am J Clin Nutr 2014;100(1):27-35.

52. Esfahani A, Wong JM, Mirrahimi A, Villa CR, Kendall C W. The application of the glycemic index and glycemic load in weight loss: a review of the clinical evidence. IUBMB Life 2011;63(1):7-13.

53. Nayak B, Berrios JD, Tang J. Impact of food processing on the glycemic index (GI) of potato products. Food Res Int 2014;56:35-46.

54. Wu X, Dhanasekaran S. Protective effect of leaf extract of Abutilon indicum on DNA damage and peripheral blood lymphocytes in combating the oxidative stress. Saudi Pharm J 2020;28(8):943-50; doi:10.1016/j.jsps.2020.06.015

55. Khalivulla SI, Mohammed A, Mallikarjuna K. novel phytochemical constituents and their potential to manage diabetes. Curr Pharm
Des 2021;27(6):775-88. Available via https://pubmed.ncbi.nlm.nih. gov/33355047

How to cite this article:

Lavanya L, Veeraraghavan V, Renuka S, Prashantha CN. Study of in vitro activity on glucose uptake of 3T3L-1 cells, RIN5f cells, and glycemic index stimulation inhibitory effect of Abutilon indicum (L.) extract. J Appl Biol Biotech 2022; 10(01):145-156. 